\title{
Complete genome sequencing and analysis of a Lancefield group G Streptococcus dysgalactiae subsp. equisimilis strain causing streptococcal toxic shock syndrome (STSS)
}

Yumi Shimomura', Kayo Okumura ${ }^{1,4}$, Somay Yamagata Murayama², Junji Yagi ${ }^{3}$, Kimiko Ubukata $^{2}$, Teruo Kirikae ${ }^{1}$, Tohru Miyoshi-Akiyama ${ }^{1 *}$

\begin{abstract}
Background: Streptococcus dysgalactiae subsp. equisimilis (SDSE) causes invasive streptococcal infections, including streptococcal toxic shock syndrome (STSS), as does Lancefield group A Streptococcus pyogenes (GAS). We sequenced the entire genome of SDSE strain GGS_124 isolated from a patient with STSS.

Results: We found that GGS_124 consisted of a circular genome of 2,106,340 bp. Comparative analyses among bacterial genomes indicated that GGS_124 was most closely related to GAS. GGS_124 and GAS, but not other streptococci, shared a number of virulence factor genes, including genes encoding streptolysin O, NADase, and streptokinase A, distantly related to SIC (DRS), suggesting the importance of these factors in the development of invasive disease. GGS_124 contained 3 prophages, with one containing a virulence factor gene for streptodornase. All 3 prophages were significantly similar to GAS prophages that carry virulence factor genes, indicating that these prophages had transferred these genes between pathogens. SDSE was found to contain a gene encoding a superantigen, streptococcal exotoxin type G, but lacked several genes present in GAS that encode virulence factors, such as other superantigens, cysteine protease speB, and hyaluronan synthase operon hasABC. Similar to GGS_124, the SDSE strains contained larger numbers of clustered, regularly interspaced, short palindromic repeats (CRISPR) spacers than did GAS, suggesting that horizontal gene transfer via streptococcal phages between SDSE and GAS is somewhat restricted, although they share phage species.
\end{abstract}

Conclusion: Genome wide comparisons of SDSE with GAS indicate that SDSE is closely and quantitatively related to GAS. SDSE, however, lacks several virulence factors of GAS, including superantigens, SPE-B and the has ABC operon. CRISPR spacers may limit the horizontal transfer of phage encoded GAS virulence genes into SDSE. These findings may provide clues for dissecting the pathological roles of the virulence factors in SDSE and GAS that cause STSS.

\section{Background}

Since Lancefield group G streptococci (GGS) have been considered components of the normal flora of the human throat, skin, and genitourinary tract, the contributions of GGS to streptococcal disease have often been overlooked [1]. Over the last decade, however, infections by pathogenic GGS have been reported, including life-

\footnotetext{
* Correspondence: takiyam@ri.ncgm.go.jp

'Department of Infectious Diseases, National Center for Global Health and

Medicine, 1-21-1, Toyama, Shinjuku-ku, Tokyo 162-8655, Japan

Full list of author information is available at the end of the article
}

threatening invasive $\beta$-hemolytic streptococcal disease [1-7], making it necessary to expand our knowledge of the pathogenesis of GGS infections, especially invasive infections. Several species of streptococci can carry group C and G antigens, including Streptococcus dysgalactiae subsp. equisimilis (SDSE), S. canis, S. dysgalactiae subsp. dysgalactiae, S. equi subsp. equi (SESE), S. equi subsp. zooepidemicus (SESZ), and S. anginosus group bacteria. SDSE, which consists of Lancefield group $\mathrm{G}$ and $\mathrm{C}$ bacteria, in a ratio of about $4: 1[3,8,9]$, has been isolated from patients at higher frequency than
C Biomed Central

(C) 2011 Shimomura et al; licensee BioMed Central Ltd. This is an Open Access article distributed under the terms of the Creative Commons Attribution License (http://creativecommons.org/licenses/by/2.0), which permits unrestricted use, distribution, and reproduction in any medium, provided the original work is properly cited. 
other GGS and GCS species. For example, of 313 strains of GCS and GGS isolated from clinical samples in Southern India between 2006 and 2007, 254 (81.1\%) were SDSE [9], as were $80 \%$ of the 266 invasive non-A and non-B $\beta$-hemolytic streptococcal isolates in the USA [3]. The spectrum and clinical courses of SDSE infection, including pharyngitis, cellulitis, infective arthritis, vertebral osteomyelitis, and streptococcal toxic shock syndrome (STSS), show substantial overlap with those of GAS [10-16]. Despite the increased clinical importance of SDSE, however, the entire SDSE genome has not yet been sequenced. Knowledge of its entire genome sequence is fundamental to gain insights into the pathogenicity of SDSE. We describe here the entire genome sequence of a Lancefield group G SDSE strain, GGS_124, which had been isolated from a patient with STSS.

\section{Results}

Selection of an SDSE isolate for genome sequencing

We chose a clinical isolate of SDSE, strain GGS_124, for genome sequence determination for several reasons. First, GGS_124 belongs to Lancefield group G, to which most clinical isolates of SDSE also belong $[3,8,9]$. Second, GGS_124 caused STSS in a patient. Third, GGS_124 was the most virulent strain among 8 group G SDSE isolates, as determined by their $\mathrm{LD}_{50}$ values in a mouse infection model (Table 1).

\section{Overview of the SDSE GGS_124 genome sequence}

We found that, similar to other streptococcal genomes, the SDSE GGS_124 genome consists of a single circular chromosome of 2,106,340 bp (Additional file 1) and has a $\mathrm{G}+\mathrm{C}$ content of $39.6 \%$ (Figure 1 ). Based on its location in the intergenic region upstream of the $d n a A$ gene (SDEG_0001), the GC skew, and the clustering of dnaA box motifs, the start point of the SDSE GGS_124 genome was assigned to the putative origin of replication

\begin{tabular}{|c|c|c|c|c|}
\hline Strain & Origin & $\begin{array}{l}\text { Symptom } \\
\text { STSS/Non- } \\
\text { STSS }\end{array}$ & $\begin{array}{l}\mathrm{LD}_{50} \text { value } \\
\text { (CFU/head) }\end{array}$ & emm type \\
\hline GGS_124 & human & STSS & $2.1 \times 10^{6}$ & stG480.0 \\
\hline 168 & human & & $4.6 \times 10^{6}$ & $s t G 480.0$ \\
\hline GGS_117 & human & STSS & $5.6 \times 10^{6}$ & stG4974.1 \\
\hline 170 & human & & $5.6 \times 10^{6}$ & stC36.0 \\
\hline 164 & human & & $1.9 \times 10^{7}$ & stG485 \\
\hline GGS_118 & human & STSS & $2.0 \times 10^{7}$ & stG67920 \\
\hline 169 & human & & $4.4 \times 10^{7}$ & stG11 \\
\hline 163 & human & & $4.5 \times 10^{7}$ & stG643 \\
\hline
\end{tabular}

$\mathrm{LD}_{50}$ values of the isolates were determined as described in MATERIALS AND METHODS.
(oriC). An AT-rich 13-mer (AGTCTGTTTTTTT), located in the intergenic region upstream of the $d n a A$ gene [17], was selected as the starting point for nucleotide numbering. The GGS_124 genome was shown to contain 2095 predicted coding sequences (CDS), which account for $1.83 \mathrm{Mbp}$ (86.9\%) of the genome. In addition, this genome was shown to harbor 3 prophage-like elements, designated ФGGS_124.1, ФGGS_124.2, and ФGGS_124.3. Moreover, there were 27 insertion sequence (IS) elements throughout the genome.

Genome sequence homology analysis of GGS_124 with the other 11 sequenced streptococcal species and subspecies showed that GGS_124 was closest in sequence to GAS, with $72 \%$ similarity (Additional file 1 ). GGS_124 was less similar to SESZ and SESE, with 65\% and $64 \%$ coverage. Although $S$. agalactiae is the closestrelati1ve of SDSE based on $16 \mathrm{~S}$ rRNA analysis, the $S$. agalactiae strains were less similar to SDSE than GAS based on the genome wide comparison (Additional file 1). In addition, we constructed a phylogenetic tree of all sequenced Streptococcus species based on the neighborjoining method (Additional file 2). Although neighborjoining methods are less accurate than the other methods such as most likelihood methods, SDSE is clustered with the GAS strains as their closest relative.

We compared the gene organization of GGS_124 with that of GAS by genomic rearrangement analyses (Figure 2 and Additional file 3). GAS could be divided roughly into 2 groups according to the orientation of the genes $[18,19]$. Therefore, SSI-1 and MGAS315, both of which are M3 serotype strains and have opposite gene orientations from each other, were chosen for the analysis. We found that the GGS_124 genome was organizationally more similar to that of GAS strain MGAS315 than GAS strain SSI-1 (Figure 2). Interestingly, the colinearity of GGS_124 and S. uberis genomes was quite remarkable but the percent amino acid identity was lower than that of the GAS strains (Additional file 3). The gene structure of GGS_124 was similar to the structures of GAS strain SSI-1, SESZ strain MGCS10565, and SESE strain 4047, although the GGS_124 genome contains largescale genomic rearrangements. The GGS_124 genome differed markedly in gene organization from the genome of GBS strain A909.

When we compared genes from GGS_124 and two relatively homologous species, GAS (MGAS315) and SESZ (MGCS10565) (Figure 3), we found that these three streptococcal genomes contain more than 1,200 orthologous genes, accounting for $59 \%$ of the total CDSs of GGS_124. GGS_124 shares 282 genes with MGAS315 and 153 genes with MGCS10565. Moreover, 71.6\% of the genes of GGS_124 were homologous to GAS genes, with $88.5 \%$ amino acid identity, whereas $66.5 \%$ of GGS_124 genes were homologous to MGCS10565 


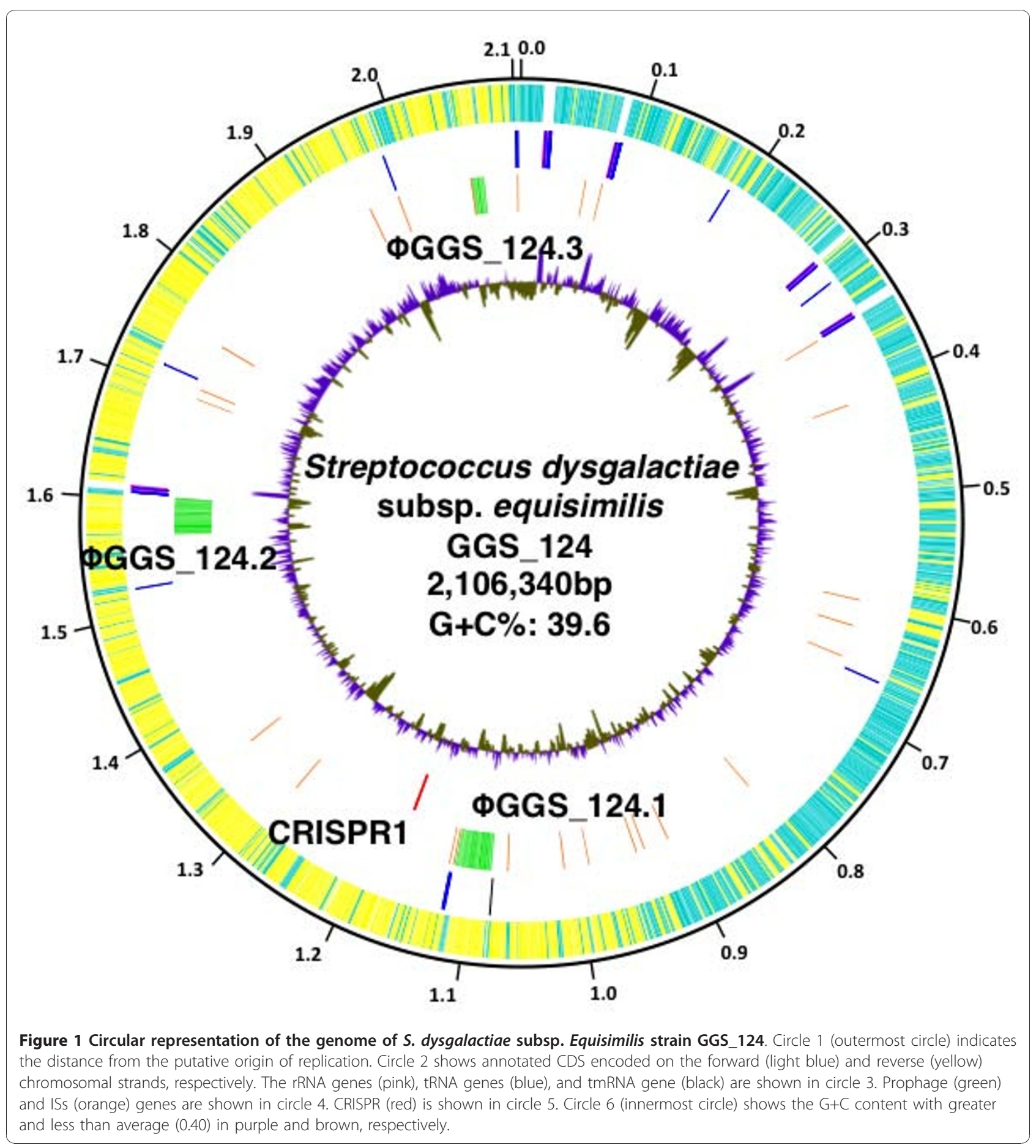

genes, with $79.9 \%$ amino acid identity. These findings indicate that SDSE is closely related to GAS in both nucleotide and amino acid sequences.

We also analyzed the distribution of genes shown to be more homologous to genes derived from bacteria other than GAS (Additional file 4). We found that 299 genes showed higher similarity to genes from Streptococci other than GAS and 92 genes showed higher similarity to genes from a genus other than Streptococcus. In addition, we identified 11 genes that did not show significant homology to any genes in the databases. These genes were scattered throughout the entire GGS_124 genome, suggesting that they had not been acquired by massive genome recombination. 


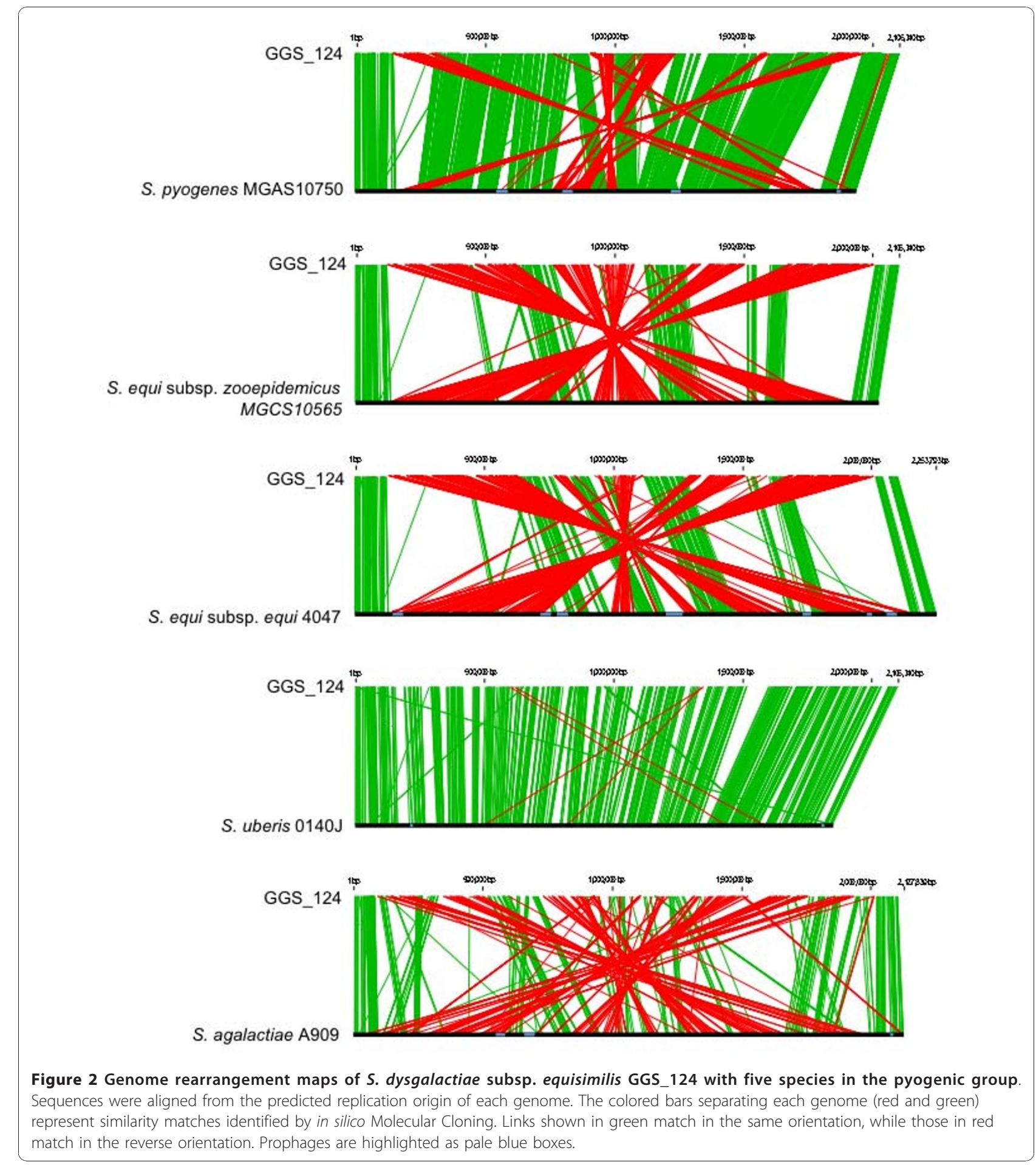

Putative prophages and CRISPR/Cas

We found that all three prophage-like elements of GGS_124 were homologous to previously sequenced GAS prophages, and that they were integrated at sites similar to those of GAS strains, with the same upstream and downstream genes (Figure 4). (i) Prophage GGS_124.1

We found that the $\Phi$ GGS_124.1 prophage is $35.593 \mathrm{bp}$ in length with a $\mathrm{G}+\mathrm{C}$ content of $38.04 \%$ and carries 60 CDS. Ninety-seven percent of the CDS in ФGGS_124.1 have homologues, with more than $40 \%$ identity to GAS prophages, suggesting that $\Phi G G S \_124.1$ is a chimeric 


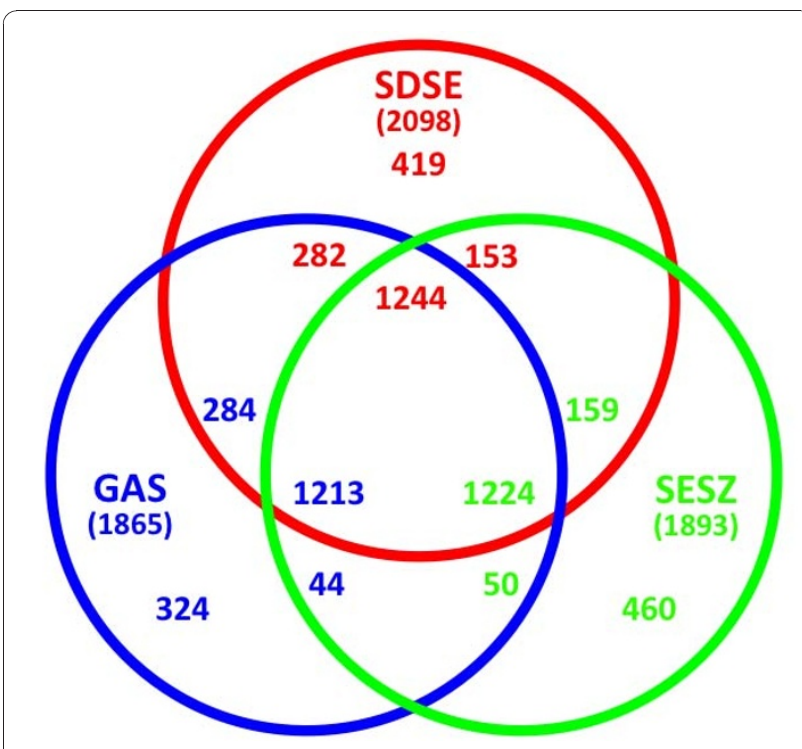

Figure 3 Venn diagram of gene content comparison among $S$. dysgalactiae subsp. equisimilis GGS_124 (SDSE), S. pyogenes MGAS315 (GAS) and SESZ MGCS10565. The inferred proteomes of SDSE, GAS, and SESZ were compared in a pairwise manner with their translated genomes by in silico Molecular Cloning and are presented as a Venn diagram. The numbers of products for each section are color coded to match the respective genomes. Genes showing more than $40 \%$ identity were considered homologues.

phage. This prophage was inserted at the predicted bacteriophage T12att site, which has been shown to be a gene that encodes a serine tRNA and is located between the CDS of SDEG_1100 and SDEG_1161 [20]. Six GAS strains, MGAS10394, MGAS315, MGAS5005, MGAS6180, MGAS8232, and SSI-1, have prophage elements: $\Phi 10394.3$, which carries speK and the streptococcal phospholipase A2 gene (sla); Ф315.2, which carries ssa; Ф5005.1, which carries speA; Ф6180.1, which carries the speC and Dnase (spd) genes; (8232.3, which carries speL and speM; and SPsP5, which carries speC, respectively [18,21-25]. In addition, ФGGS_124.1 was found to contain a prophage-associated virulence factor gene for deoxyribonuclease $(s d c)$.

\section{(ii) Prophage GGS_124.2}

We found that the $\Phi$ GGS_124.2 prophage is 35,814 bp in length, with a $\mathrm{G}+\mathrm{C}$ content of $38.20 \%$ and $61 \mathrm{CDS}$. Ninety-five percent of the CDS in TGGS_124.1 have homology with genes in GAS prophages, making it likely that $\Phi$ GGS_124.2 is chimeric phage. The chromosomal phage attachment site (attB) and the $\Phi$ GGS_124.2 phage-encoded attachment site $(a t t P)$ were not found, but the products of $a t t P / a t t B$ recombination, att $L$ and $a t t R$, with the same sequences as those of GAS prophages SPsP2 and $\Phi 315.5$ were identified. The genome context around the integration site for $\Phi$ GGS_124.2 was found to be conserved at the phage integration sites of 4 GAS strains, MGAS10394, MGAS315, SSI-1, and Manfredo, which contain the prophage elements $\Phi 10394.6$, carrying $s d n$; Ф315.5, carrying speA; SPsP2, carrying speA; and phiMan.1, carrying the DNase gene $m f 3$, respectively $[18,19,21,22]$. No known prophage-associated virulence factor genes were found in $\Phi$ GGS_124.2.

\section{(iii) Prophage GGS_124.3}

We also found a prophage remnant, ФGGS_124.3, which was about $12.6 \mathrm{~kb}$ length and homologous to the previously sequenced GAS prophage remnants $\Phi 6180.4$ and $\Phi 10270.5$ with a nucleotide identity of $73 \%$. ФGGS_124.3 and the two GAS phage remnants were found to be located between genes encoding a putative transcriptional regulator protein and the $30 \mathrm{~S}$ ribosomal protein. In strain GGS_124, two truncated transposase proteins, SDEG_2117 and SDEG_2118, were found to be inserted upstream of GGS_124.3. No virulence factor genes are present in GGS_124.3.

Prokaryotes possess a system that mediates resistance to infection by foreign DNA, such as viruses [26,27]. When bacteria are exposed to phages, short fragments derived from phage DNA are integrated into clusters of regularly interspaced short palindromic repeat (CRISPR) regions of the bacterial genome as spacers [27]. CRISPR RNA transcripts and CRISR-associated proteins (Cas), act in complexes to interfere with virus proliferation [26]. This system has also been observed in GAS [20], SESZ [22,28], S. mutans [29], and S. thermophilus [30]. GGS_124 harbors a CRISPR/Cas system consisting of an array of genes, can1, cas1, cas2, and csn2, and CRISPR (Figure 5). The GGS_124 CRISPR has 19 direct repeats of $36 \mathrm{bp}$ each and 18 spacer sequences 30 or $32 \mathrm{bp}$ in length; 6 of these sequences are homologous to GAS prophage sequences, with more than $80 \%$ coverage (Additional file 5). When we analyzed the number of CRISPR spacers in an additional 7 SDSE isolates (Table 2), we found that the mean number of CRISPR spacers was higher in SDSE $(18.0 \pm 3.3$ spacers $)$ than in GAS strains ( $4.0 \pm 1.0$ spacers; range, 0 to 9 ) (Table 2). These results suggest that prophage infection of SDSE is somewhat restricted, resulting in a smaller number of virulence factors located in the prophage regions of SDSE. Alternatively, SDSE may be in contact with phages more frequently, with integrated phages having a fitness cost for SDSE.

\section{Virulence factors encoded by the GGS_124 genome}

An analysis of 58 SDSE strains isolated from human infections using targeted microarrays containing 216 GAS virulence genes composed of 70 mer oligonucleotides showed that about $50 \%$ of the GAS virulence genes represented in the microarray were present in SDSE [31]. Three molecular markers, speB, the intergenic region upstream of the $s c p G$ gene and $v i r P C R$, have 


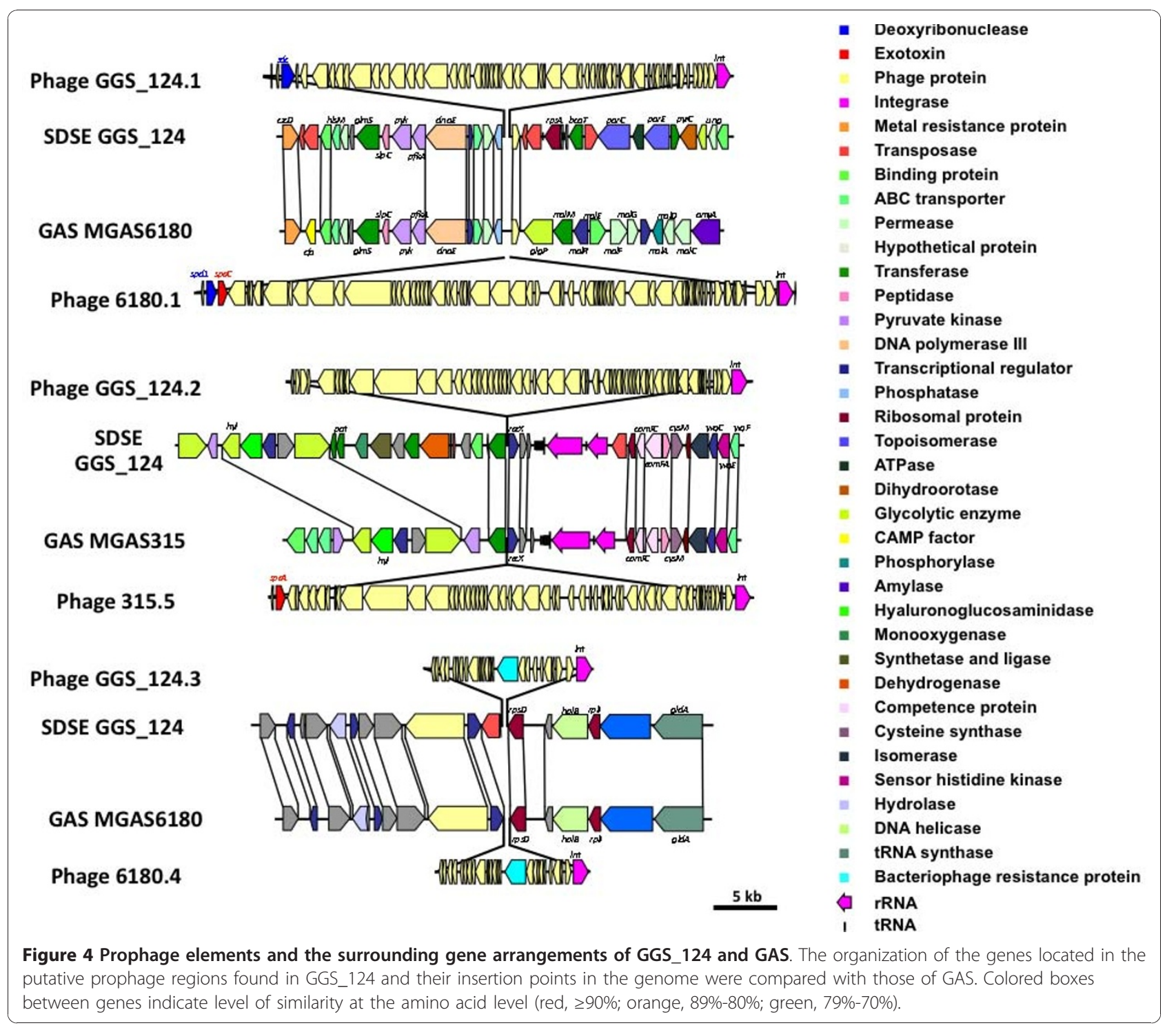

been shown helpful in discriminating between GAS and SDSE [32]. Based on homology analyses with known bacterial virulence factors, such as pore-forming toxins, a superantigen, proteases, FCT-like regions, adhesins, hyaluronidase, and a nuclease, we identified 71 putative virulence factor genes in the GGS_124 genome; their details are shown in Additional file 6. Comparison of the virulence factors in GGS_124 with those of other streptococcal species indicated that the putative virulence factors most similar to those of GGS_124 were found in GAS. In contrast, superantigen, SPE-B and the has operon of GAS are not conserved in GGS_124.

\section{(i). Pore-forming toxins}

GGS_124 has several putative hemolysins, including HlyX (SDEG_0427), HlyIII (SDEG_1015), and HlyA1 (SDEG_1483), which have also been detected in GAS, SESZ, SESE, S. uberis, and GBS. GGS_124 also has genes encoding streptolysin S (sagA) (SDEG_0705) and its biosynthesis proteins (sagBCDEFGHI) (SDEG_0706 to 0713), which are also present in GAS [33], SESZ, and SESE $[22,28,34]$. In addition, GGS_124 carries a gene for streptolysin O (SLO) (SDEG_2027), which is essential for GAS virulence and is required for the organism to escape from the endosome into the cytosol following invasion of host cells [35].

\section{(ii). Superantigen}

GGS_124 possesses only one superantigen gene, exotoxin G variant 4 (spegg4), which is homologous to GAS streptococcal exotoxin G (SpeG), with 79\% amino acid identity (Additional file 6). In a previous analysis of the superantigenic activities of the spegg 4 product in human peripheral blood mononuclear cells [36], we found that its mitogenic activity was about $1 \%$ that of SpeG from GAS. Other genome-encoded superantigen 


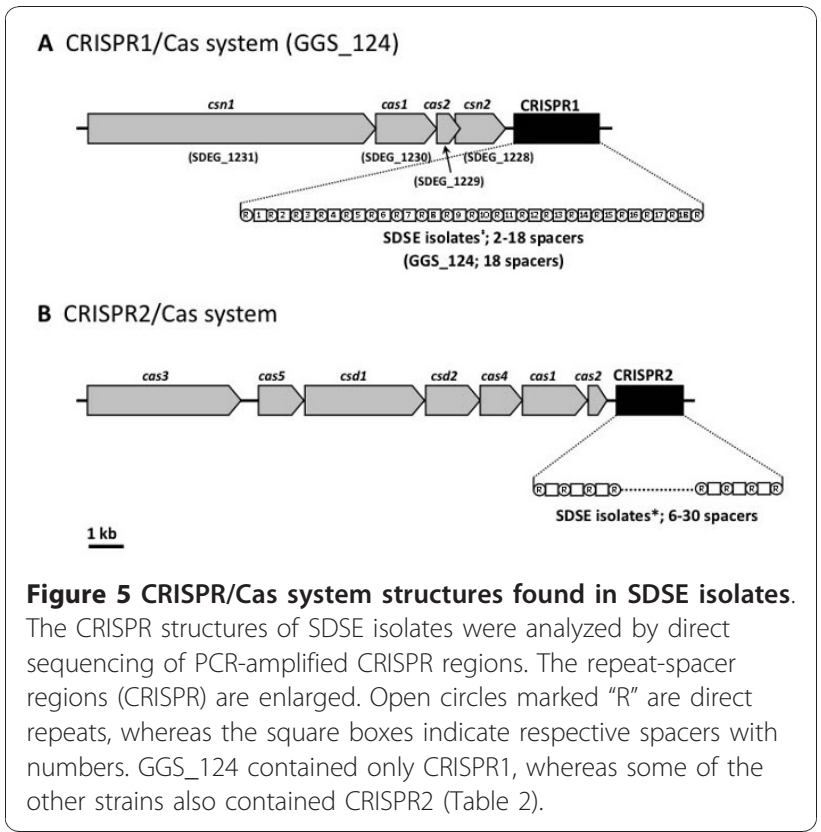

genes for mitogenic exotoxin $\mathrm{Z}$ (smeZ), which are present in GAS [37], were not found in the GGS_124 genome.

\section{(iii) Proteases}

We found that a putative proteinase (SDEG_1906) and streptococcal C5a peptidase (scpB) (SDEG_0933) [38] were conserved among GGS_124 and 5 closely related species. GGS_124 also has a gene with homology (42\% amino acid identity) to exfoliative toxin A of Staphylococcus aureus strain Mu50 (SAV1173), which causes staphylococcal scalded skin syndrome [39]. GGS_124 also carries a gene for streptokinase (SDEG_0233), similar to streptokinase A of GAS, with $88 \%$ amino acid identity (Additional file 6). This protein complexes with plasminogen to form an activator, which has serine protease activity and cleaves free plasminogen. leading to activation of the zymogen [40]. Strikingly, GGS_124 lacks streptococcal cysteine protease (SpeB), an erythrogenic toxin produced by GAS with cysteine protease activity [41]. The GGS_124 genome lacks approximately $7 \mathrm{~kb}$ of

Table 2 Presence of Cas genes and the number of spacers in CRISPR1/Cas and CRISPR2/Cas

\begin{tabular}{|c|c|c|c|c|c|c|c|}
\hline \multirow[b]{2}{*}{ Species } & \multirow[b]{2}{*}{ Strain } & \multicolumn{3}{|c|}{ CRISPR1/Cas } & \multicolumn{3}{|c|}{ CRISPR2/Cas } \\
\hline & & Cas genes & No. of spacers & Acc. No. & Cas genes & No. of spacers & Acc. No \\
\hline \multirow[t]{8}{*}{ Streptococcus dysgalactiae subsp. equisimilis } & GGS_124 & + & 18 & AP010935.1 & - & 0 & - \\
\hline & 168 & + & 2 & AB553332 & + & 13 & AB553333 \\
\hline & GGS_117 & + & 8 & AB553338 & + & 12 & AB553339 \\
\hline & 170 & + & 9 & AB553336 & + & 10 & AB553337 \\
\hline & 164 & + & 17 & AB553343 & + & 6 & AB553331 \\
\hline & GGS_118 & + & 8 & AB553342 & + & 13 & AB553341 \\
\hline & 169 & + & 7 & AB553334 & + & 30 & AB553335 \\
\hline & 163 & + & 3 & AB553340 & N. D. & N. D. & \\
\hline \multirow[t]{13}{*}{ Streptococcus pyogenes } & MGAS8232 & - & 0 & AE009949.1 & - & 0 & OAE009949.1 \\
\hline & MGAS10394 & & 0 & СР000003.1 & - & 0 & СР000003.1 \\
\hline & MGAS10750 & + & 0 & СР000262.1 & + & 5 & СР000262.1 \\
\hline & Manfredo & - & 0 & AM295007.1 & - & 0 & AM295007.1 \\
\hline & MGAS10270 & + & 2 & СР000260.1 & + & 3 & СР000260.1 \\
\hline & MGAS315 & + & 0 & AE014074.1 & - & 0 & AE014074.1 \\
\hline & MGAS5005 & + & 3 & СР000017.1 & + & 4 & СР000017.1 \\
\hline & MGAS9429 & + & 0 & СР000259.1 & + & 7 & СР000259.1 \\
\hline & MGAS2096 & + & 0 & СР000261.1 & + & 6 & СР000261.1 \\
\hline & SF370 & + & 6 & AE004092.1 & + & 3 & AE004092.1 \\
\hline & SSI-1 & + & 0 & BA000034.2 & - & 0 & BA000034.2 \\
\hline & MGAS6180 & + & 4 & CP000056.1 & + & 1 & СР000056.1 \\
\hline & NZ131 & + & 4 & CP000829.1 & + & 5 & CP000829.1 \\
\hline \multirow[t]{2}{*}{ Streptococcus equi subsp. zooepidemicus } & MGCS10565 & + & 17 & СР001129.1 & + & 9 & СР001129.1 \\
\hline & $\mathrm{H} 70$ & - & 0 & FM204884.1 & + & 18 & FM204884.1 \\
\hline Streptococcus equi subsp. equi & 4047 & - & 0 & FM204883.1 & - & 0 & FM204883.1 \\
\hline
\end{tabular}

N.D.: No amplicon was obtained in PCR analyses. 
the GAS strain MGAS315 sequence, including genes encoding SpeB (SpyM3_1742), the transcriptional regulator RopB (SpyM3_1744), and mitogenic factor 25K precursor (SpyM3_1745). Since several transposase and related genes (SDEG_0212, 0206, 0205, 0201, 0194) are located in the corresponding region, it is highly likely that the region that included speB was present in the common ancestor of GAS and SDSE but was not retained by SDSE after speciation.

We found that $s p e B$ was not present in GGS_124, in agreement with the results of a microarray study, which showed that all of the 58 examined strains of group $C$ and G SDSE isolated from patients lacked the speB gene $[31,32]$. We therefore examined whether SDSE strains have protease activity similar to that of SpeB (Additional file 7). We did not detect any SpeB-like protease activity in strains GGS_124 or GGS_118, which had been isolated from two patients with STSS. In contrast, a GAS strain produced a proteinase that was sensitive to E-64, which inhibits cysteine proteases, including SpeB.

\section{(iv) FCT-like regions}

Recently, GAS and GBS were shown to express pili, which are synthesized by proteins encoded by genes in FCT regions [1,42,43]. GGS_124 harbors 2 FCT-like regions, which are probable operons expressing different pilus-like structures (Figure 6). One of these contains genes encoding the transcriptional regulator RofA (SDEG_0156), two putative fimbrial structural subunit proteins (SDEG_0157 and SDEG_0158), two sortases (SDEG_0159 and
SDEG_0160), and a putative fibronectin binding protein (SDEG_0161). It is similar to the FCT-6 region, which is conserved among M2 GAS, GBS, and SESZ [22,42,44]. The second region contains genes encoding a putative transcriptional regulator (SDEG_1782), a defective collagen binding protein (SDEG_1781), a signal peptidase I (SDEG_1780), a backbone protein (SDEG_1779), and an ancillary protein (SDEG_1778). It is similar to the FCT-3 region, which was found in M3, M5, M18, and M49 GAS [43].

\section{(v) Adhesins}

GGS_124 possesses genes that encode putative adhesion proteins, including proteins similar to putative fibronectin binding proteins (SDEG_0161, 1263, and 1984), pullulanase (SDEG_0237), phosphopyruvate hydratase (SDEG_0704), laminin binding protein (SDEG_0935), internalin protein (SDEG_1372), and collagen binding protein (SDEG_1781), all of which bind to the extracellular matrix (Additional file 6). SGGS_124 also possesses genes encoding immunoglobulin $G$ binding protein (SDEG_1358) [45] and multifunctional streptococcal plasmin receptor (Plr)/streptococcal surface dehydrogenase (SDH)/glyceraldehyde-3-phosphate dehydrogenase (GAPDH), which binds to complement component C5a (SDEG_1936) [46] (Additional file 6), although the product of SDEG_1936 lacks a signal peptide.

\section{(vi) Hyaluronan capsule synthesis}

Hyaluronic acid (HA), synthesized via the has $A B C$ operon, is considered a pleiotropic virulence factor involved in
SDSE GGS_124
pilus-like structure genes 1

M2 GAS MGAS10270 (FCT-6)

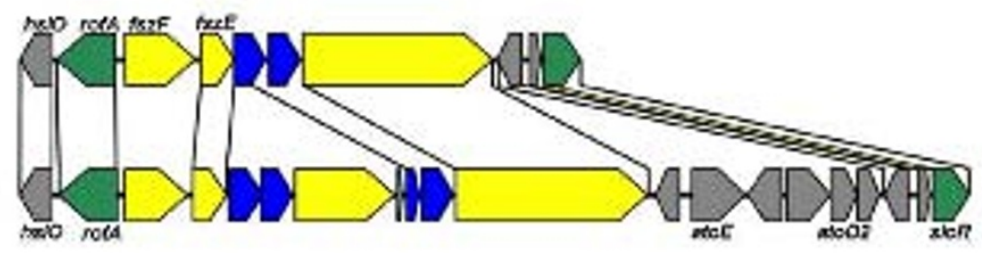

SDSE GGS_124

pilus-like structure genes 2

M3 GAS MGAS315 (FCT-3)

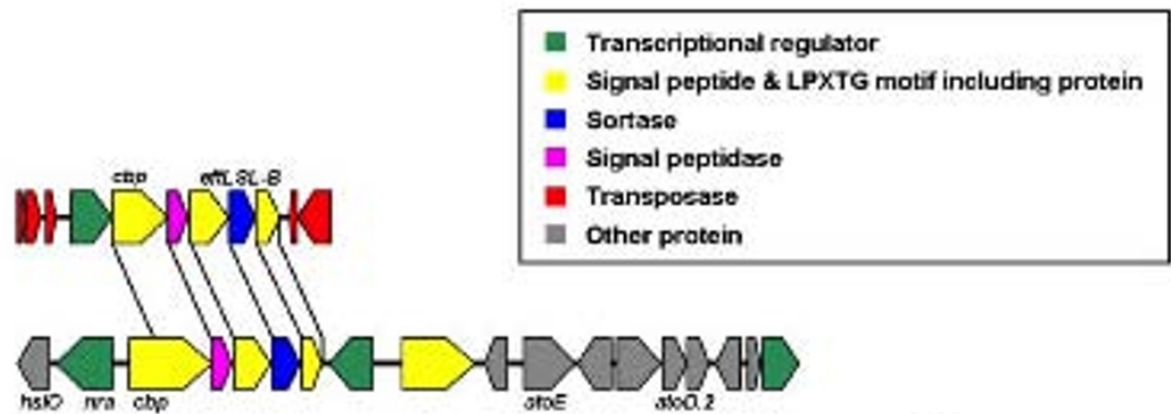

$5 \mathrm{~kb}$

Figure 6 Organization of genes encoding pilus-like structure proteins in S. dysgalactiae subsp. equisimilis GGS_124. The organizations of genes encoding pilus-like structure proteins in GGS_124 were compared with those in GAS and SESZ. Colored boxes between genes indicate similarity at the amino acid level (red, 290\%; orange, 90\%-80\%; yellow-green, 79\%-70\%; green, 69\%-60\%; purple, 59\%-40\%; gray, <40\%). 
many aspects of GAS infection [47]. GGS_124, however, does not contain an has $A B C$ operon, in contrast to the genomes of GAS, SESZ, SESE, and S. uberis. Rather, GGS_124 possesses only one gene, encoding glycosyl transferase (SDEG_0628), which shows a low level of similarity to has A of GAS (20\% amino acid similarity). Although one SDSE strain has been shown to possess a hyaluronan synthase (AF023876.1), very similar to the product of hasA [48], GAS gene microarray analysis of 58 SDSE strains isolated from human infections showed that all harbored only hasC [31]. We found that GGS_124 also harbors only hasC (SDEG_1980) (Additional file 6), making it unlikely that SDSE produces HA via the has $A B C$ operon.

\section{(vii) Hyaluronidase}

GGS_124 possesses a gene in a non-prophage region of the genome that encodes a putative hyaluronidase (SDEG_0654), with 66\% identity to hylB in SESZ (Additional file 6). Hyaluronidase in GAS is thought to contribute to the spread of bacteria in tissues and may allow GAS to utilize host hyaluronic acid or its own capsule as an energy source [49]. The hyaluronidase in GGS_124 may have a function similar to that in GAS.

\section{(viii) Nucleases}

GGS_124 possesses 5 genes that encode putative nucleases with a secretion signal peptide: genome-encoded streptodornase (SDEG_0541), extracellular nuclease (SDEG_0714), DNA-entry nuclease (SDEG_0732), cell surface 5'-nucleotidase (SDEG_0825), and prophage-associated deoxyribonuclease (SDEG_1103), all of which are predicted to code for a secretion signal peptide. Two of them, SDEG_0714 and SDEG_0825, code for potential cell wall anchor motifs, LPKAG and LPMAG, respectively (Additional file 6). The putative streptodornase SDEG_0541 and DNA-entry nuclease SDEG_0732 are homologous to phage-encoded extracellular streptodornase D Sda1 of GAS (PHA01790) [50] and DNA-entry nuclease EndA of S. pneumoniae TIGR4 (SP_1964) [51], respectively (Additional file 6). Sda1 and EndA have been found to degrade neutrophil extracellular traps (NETs) [50,51], which are composed of granule proteins and chromatin released by neutrophils and can catch and kill surrounding bacteria [52]. The putative extracellular DNase SDEG_0714 is similar to M1 GAS cellwall-located DNase SpnA (Spy0747), which has been reported important for virulence, e.g., dispersion in host tissue [53] (Additional file 6).

\section{(ix) Other virulence factors}

GGS_124 possesses genes encoding the multifunctional M protein (stg480.0) (SDEG_0230). The M protein of GAS shows antiphagocytic and adhesin activities, whereas the adhesion function of the GGS M protein may be due to a collagen binding motif $[54,55]$. Since the product of $\operatorname{Stg} 480.0$ lacks this motif, the M protein of GGS_124 may not act as an adhesin.
Streptococcal inhibitor of complement (SIC) and distantly related to SIC (DRS) are some extent of homology. DRS binds complement factors but does not inhibit complement mediated cell lysis [56,57], whereas SIC inhibits complement mediated cell lysis [58]. GGS_124 harbors a putative DRS gene (SDEG_0932), which consists of a signal sequence, two repeat regions, and a proline-rich region typical of DRS, and is homologous to the Drs12.04 protein of GAS strain emm12 with $48 \%$ amino acid identity [59] (Additional file 6).

The GGS_124 genome harbors a gene encoding a collagen-like protein (SDEG_1113), similar to the collagen-like repeat phage protein of SESE 4047 (SEQ_0837), with 41\% amino acid identity. Streptococcal collagen-like proteins $(\mathrm{Scl})$ are cell-surface molecules of GAS with domains containing tracks of repeated GlyXaa-Yaa sequences that form a mammalian collagen-like triple-helical structure. These proteins mediate the internalization of GAS into human cells upon binding of $\mathrm{Scl}$ to the human collagen receptor integrin [60]. The GGS_124 gene encoding collagen-like protein does not contain a signal peptide or LPXTG motif, suggesting that the gene product may not be expressed on the cell surface. In contrast, GGS_124 does not harbor genes encoding proteins similar to the other collagen-like proteins $(s c l A$ and $s c l B)$ in GAS.

NAD glycohydrolase (SDEG_2029), which is located in the NADase-streptolysin O operon of the GAS genome [61], was found to be conserved in the same operon in GGS_124 (Additional file 6). This enzyme is expressed after streptolysin $\mathrm{O}$ is injected into host cells and accelerates cell death $[61,62]$.

(x) Distribution of virulence factors among Streptococci

We also assessed the presence or absence of representative virulence factors among sequenced streptococcal species, including GAS (MGAS315), SESE (4047), SESZ (MGCS10565), GBS (A909), and S. uberis (0140J) (Additional file 8). Among 30 virulence factors, most of those located in the core genome, but not those located in streptococcal phages, are conserved in GGS_124, except for speB. In contrast, other streptococci lack genes encoding streptolysin O, NAD glycohydrolase and DRS (or SIC), suggesting the importance of these proteins in the pathogenicity of SDSE and GAS in humans, causing STSS.

\section{Putative virulence factors unique to SDSE}

We identified 20 gene products in GGS_124 containing signal peptides and LPXTG cell wall surface anchor motifs that showed low similarity to known proteins. Using PCR, we analyzed the distributions of these putative virulence factors in 8 SDSE isolates (Table 3 arranged according to their decreasing lethality in mice). A putative $\mathrm{T}$-antigen-like protein structural subunit 
Table 3 Putative virulence factors found in GGS_124 and their prevalence in the SDSE isolates based on the results of PCR analyses

\begin{tabular}{|c|c|c|c|c|c|c|c|c|c|c|c|c|c|c|c|}
\hline \multirow[b]{2}{*}{ Locus tag } & \multicolumn{4}{|c|}{ S. dysgalactiae subsp. equisimilis GGS_124 } & \multicolumn{3}{|c|}{ Best hit strain } & \multicolumn{8}{|c|}{ PCR analysis } \\
\hline & Product name & $\begin{array}{l}\text { Length } \\
\text { (aa) }\end{array}$ & $\begin{array}{l}\text { LPXTG } \\
\text { motif }\end{array}$ & $\begin{array}{c}\% \\
\text { Identity }\end{array}$ & Strain & Product name & $\begin{array}{l}\text { Reference } \\
\text { sequence }\end{array}$ & $\begin{array}{l}\text { GGS } \\
-124\end{array}$ & 168 & $\begin{array}{r}\text { GGS } \\
\_117\end{array}$ & 170 & 164 & $\begin{array}{l}\text { GGS } \\
-118\end{array}$ & 169 & 163 \\
\hline & & & & & Streptococcus equi & & & & & & & & & & \\
\hline & fimbrial subunit & & & & $\begin{array}{l}\text { subsp. } \\
\text { zooepidemicus }\end{array}$ & fimbrial subunit & & & & & & & & & \\
\hline \multirow[t]{3}{*}{ SDEG_0157 } & Protein & 645 & IPNTG & 40.48 & MGCS10565 & protein & YP_002124169.1 & Yes & $x$ & $x$ & $x$ & $x$ & $x$ & $x$ & $x$ \\
\hline & $\begin{array}{l}\text { T-antigen-like } \\
\text { fimbrial }\end{array}$ & & & & Streptococcus equi & $\begin{array}{l}\text { T-antigen-like } \\
\text { fimbrial }\end{array}$ & & & & & & & & & \\
\hline & structural subunit & & & & $\begin{array}{l}\text { subsp. } \\
\text { zooepidemicus }\end{array}$ & structural subunit & & & & & & & & & \\
\hline SDEG_0158 & protein & 315 & IPKTG & 49.84 & MGCS10565 & protein & YP_002124168.1 & Yes & Yes & Yes & $x$ & $x$ & $x$ & $x$ & $x$ \\
\hline \multirow[t]{3}{*}{ SDEG_0180 } & $\begin{array}{l}\text { hypothetical } \\
\text { protein }\end{array}$ & 184 & & - & No hit & - & - & Yes & Yes & Yes & Yes & Yes & Yes & Yes & Yes \\
\hline & hypothetical & & & & & hypothetical & & & & & & & & & \\
\hline & $\begin{array}{l}\text { membrane } \\
\text { associated }\end{array}$ & & & & $\begin{array}{l}\text { Streptococcus } \\
\text { pyogenes }\end{array}$ & $\begin{array}{l}\text { membrane- } \\
\text { associated }\end{array}$ & & & & & & & & & \\
\hline \multirow[t]{2}{*}{ SDEG_0267 } & protein & 242 & & 44.35 & MGAS2096 & Protein & YP_601272.1 & Yes & Yes & Yes & Yes & Yes & Yes & Yes & Yes \\
\hline & cell surface serine & & & & Streptococcus & & & & & & & & & & \\
\hline \multirow[t]{3}{*}{ SDEG_0574 } & endopeptidase & 216 & & 49.36 & Agalactiae & CspA & AAN85092.1 & Yes & Yes & Yes & Yes & Yes & Yes & Yes & Yes \\
\hline & & & & & Streptococcus equi & & & & & & & & & & \\
\hline & cell wall surface & & & & $\begin{array}{l}\text { subsp. } \\
\text { zooepidemicus }\end{array}$ & cell wall surface & & & & & & & & & \\
\hline \multirow[t]{3}{*}{ SDEG_0805 } & $\begin{array}{l}\text { anchor family } \\
\text { protein }\end{array}$ & 486 & LPKAG & 43.73 & MGCS10565 & $\begin{array}{l}\text { anchor family } \\
\text { protein }\end{array}$ & YP_002123384.1 & Yes & Yes & $x$ & $x$ & Yes & $x$ & $x$ & Yes \\
\hline & & & & & Streptococcus equi & & & & & & & & & & \\
\hline & & & & & $\begin{array}{l}\text { subsp. } \\
\text { zooepidemicus }\end{array}$ & $\begin{array}{l}\text { histidine triad } \\
\text { protein }\end{array}$ & & & & & & & & & \\
\hline \multirow[t]{2}{*}{ SDEG_0918 } & $\begin{array}{l}\text { histidine triad } \\
\text { protein }\end{array}$ & 153 & & 51.35 & MGCS10565 & $\mathrm{HtpA}$ & YP_002123384.1 & Yes & Yes & Yes & Yes & Yes & Yes & Yes & Yes \\
\hline & $\begin{array}{l}\text { complement } \\
\text { inhibitor }\end{array}$ & & & & $\begin{array}{l}\text { Streptococcus } \\
\text { pyogenes }\end{array}$ & $\begin{array}{l}\text { complement } \\
\text { inhibitor }\end{array}$ & & & & & & & & & \\
\hline \multirow[t]{2}{*}{ SDEG_0932 } & protein & 226 & & 47.92 & MGAS2096 & protein & YP_601343.1 & Yes & $x$ & $x$ & $x$ & $x$ & Yes & $x$ & $x$ \\
\hline & nisin resistance & & & & Streptococcus & nisin resistance & & & & & & & & & \\
\hline \multirow[t]{2}{*}{ SDEG_0979 } & protein, putative & 322 & & 42.17 & agalactiae $2603 \mathrm{~V} / \mathrm{R}$ & Protein & NP_687984.1 & Yes & Yes & Yes & Yes & Yes & Yes & Yes & Yes \\
\hline & & & & & Streptococcus & & & & & & & & & & \\
\hline \multirow[t]{2}{*}{ SDEG_1327 } & $\begin{array}{l}\text { YaeC family protein } \\
\text { probable surface }\end{array}$ & 280 & & 49.47 & agalactiae $2603 \mathrm{~V} / \mathrm{R}$ & $\begin{array}{l}\text { YaeC family protein } \\
\text { probable surface }\end{array}$ & NP_687791.1 & Yes & Yes & Yes & Yes & Yes & Yes & Yes & Yes \\
\hline & antigen negative & & & & Streptococcus suis & antigen negative & & & & & & & & & \\
\hline \multirow[t]{2}{*}{ SDEG_1429 } & regulator & 185 & & 52.22 & $98 \mathrm{HAH} 33$ & regulator Par & YP_001200806.1 & Yes & $x$ & Yes & Yes & Yes & Yes & $x$ & Yes \\
\hline & & & & & $\begin{array}{l}\text { Streptococcus } \\
\text { pyogenes }\end{array}$ & & & & & & & & & & \\
\hline
\end{tabular}


Table 3 Putative virulence factors found in GGS_124 and their prevalence in the SDSE isolates based on the results of PCR analyses (Continued)

\begin{tabular}{|c|c|c|c|c|c|c|c|c|c|c|c|c|c|c|c|}
\hline SDEG_1480 & $\begin{array}{l}\text { hypothetical } \\
\text { protein }\end{array}$ & 299 & LPVTG & 33.33 & MGAS6180 & $\begin{array}{l}\text { hypothetical } \\
\text { protein }\end{array}$ & YP_280631.1 & Yes & $x$ & Yes & Yes & Yes & Yes & Yes & Yes \\
\hline \multirow[t]{2}{*}{ SDEG_1511 } & $\begin{array}{l}\text { hypothetical } \\
\text { protein }\end{array}$ & 546 & & 27.59 & Streptococcus suis & $\begin{array}{l}\text { hypothetical } \\
\text { protein }\end{array}$ & ABQ42885.1 & Yes & Yes & Yes & Yes & Yes & Yes & Yes & Yes \\
\hline & & & & & Streptococcus uberis & & & & & & & & & & \\
\hline SDEG_1573 & adhesion protein & 661 & LPKTG & 38.8 & UT888 & adhesion protein & ABB52003.1 & Yes & Yes & $x$ & $x$ & $x$ & $x$ & $x$ & Yes \\
\hline \multirow[t]{2}{*}{ SDEG_1601 } & $\begin{array}{l}\text { hypothetical } \\
\text { protein }\end{array}$ & 249 & & - & No hit & - & - & Yes & $x$ & Yes & $x$ & $x$ & Yes & $x$ & $x$ \\
\hline & & & & & $\begin{array}{l}\text { Streptococcus } \\
\text { pyogenes }\end{array}$ & & & & & & & & & & \\
\hline \multirow[t]{2}{*}{ SDEG_1773 } & $\begin{array}{l}\text { hypothetical } \\
\text { protein }\end{array}$ & 210 & FPSTG & 37.96 & M1 GAS & $\begin{array}{l}\text { hypothetical } \\
\text { protein }\end{array}$ & NP_268519.1 & Yes & Yes & Yes & $x$ & $x$ & Yes & Yes & Yes \\
\hline & & & & & $\begin{array}{l}\text { Streptococcus } \\
\text { sanguinis }\end{array}$ & & & & & & & & & & \\
\hline \multirow[t]{3}{*}{ SDEG_1969 } & $\begin{array}{l}\text { hypothetical } \\
\text { protein }\end{array}$ & 234 & & 32.77 & SK36 & $\begin{array}{l}\text { hypothetical } \\
\text { protein }\end{array}$ & YP_001035903.1 & Yes & Yes & Yes & Yes & Yes & Yes & Yes & Yes \\
\hline & protein F2-like & & & & Streptococcus equi & & & & & & & & & & \\
\hline & fibronectin binding & & & & $\begin{array}{l}\text { subsp. } \\
\text { zooepidemicus }\end{array}$ & fibronectin binding & & & & & & & & & \\
\hline SDEG_1984 & Protein & 528 & LPATG & 40.46 & ATCC 35246 & protein & ABC87919.1 & Yes & $x$ & $x$ & Yes & Yes & x & Yes & Yes \\
\hline SDEG_2022 & $\begin{array}{l}\text { hypothetical } \\
\text { protein }\end{array}$ & 106 & & - & No hit & - & - & Yes & Yes & Yes & Yes & Yes & Yes & Yes & Yes \\
\hline SDEG_2141 & $\begin{array}{l}\text { hypothetical } \\
\text { protein }\end{array}$ & 175 & & - & No hit & - & - & Yes & x & $x$ & $x$ & Yes & x & $x$ & Yes \\
\hline
\end{tabular}

Genes encoding proteins, which contain predicted signal peptide based on SignalP http://www.cbs.dtu.dk/services/SignalP and the LPXTG motif based on HMMER http://bamics3.cmbi.kun.nl/jos/sortase_substrates/ help.html and were not highly homologous to putative virulence factors of GGS_124. Distribution of the putative virulence factors of GGS_124 in the 16 SDSE strains was analyzed by PCR, and the results are presented as SDSE strains in order of decreasing lethality in mice. Yes: PCR analysis postive; x: PCR analysis negative. 
(SDEG_0158), encoded in the FCT-6-like region in GGS_124, was detected in the 3 most virulent strains, GGS_124, GGS_168, and GGS_117. In both GGS_168 and GGS_117, the FCT-6-like region was not detected by PCR (data not shown). Interestingly, the SDEG_1601 gene encoding a functionally unknown hypothetical protein was amplified in isolates that cause STSS. However, no virulence factors associated with mouse lethality or Lancefield groups were found.

\section{Relatedness of emm type and pathogenicity in SDSE}

Particular M (or emm) types of GAS have been associated with certain streptococcal diseases [63]. In investigating the pathogenic traits of M4, M12, M1, and M3 GAS clinical isolates in a murine model [64], we found that murine lethality was closely associated with $M$ type. The M1 and M3 types of GAS, which are isolated at high frequency from patients with STSS, showed higher virulence in mice than did M12 and M4. Using this mouse model, we assessed the virulence of the $\mathrm{emm}$ types of 8 group G SDSE isolates to analyze whether most frequent emm-type of isolates in epidemiological studies (see below) are more virulent in mice (Table 1). We found that the lethality in mice of these isolates was not associated with their isolation from patients with STSS or with the frequently isolated emm-type in humans such as stG10.0 and stG643.0 (see below). To determine whether the emm type of SDSE was associated with pathogenicity in humans, we reviewed the epidemiological data regarding the isolation frequencies of GCS and GGS in relation to their emm types $[3,6,7,65,66]$ (Additional file 9). We found that stG10.0 was the most frequent emm type in Portugal and Japan, $s t$ G643.0 was the most frequent in western Norway, and $s t G 6.0$ was the most frequent in the USA. When we calculated the degree of correspondence among the isolation rates of emm types in each area using the Kendall tau rank correlation coefficient, we found no significant correlations among all regions (data not shown), suggesting that there is no linkage between emm type of SDSE and infectivity in humans or mice.

\section{Discussion}

Comparative analysis of Streptococcus 16S rRNA sequences had indicated that SDSE was more closely related to GBS than to GAS $[67,68]$. In contrast, we found that SDSE, which belongs to Lancefield groups $C$ and $\mathrm{G}[3,65]$, is more closely related to GAS than to other sequenced streptococci based on genome wide and gene level comparisons

SDSE is known to cause diseases very similar to those caused by GAS, such as pharyngitis, cellulitis, infective arthritis, vertebral osteomyelitis, and STSS [10-16]. This similarity may be due, at least in part, to their conservation of a large number of genes for virulence factors. Figure 7 shows a summary of putative virulence factors and proposed virulence functions in SDSE. SDSE shares most of the virulence factor genes of GAS, including streptolysin $\mathrm{O}$, streptokinase, FCT-like regions, NADase, and DRS. However, GGS_124 and probably almost all other SDSEs lack SpeB, superantigens except for SpeG, and hyaluronan synthesis via has $A B C$ [31]. As spegg4, which has about $1 \%$ of the mitogenic activity of GAS-derived SpeG, is the only gene encoding a protein homologous to superantigens, and most SDSE isolates do not harbor superantigen-like genes other than spegg $[31,69]$, it is highly unlikely that superantigens play a significant role in the pathogenesis of SDSE infection in humans.

Particular M (or emm) types of GAS have been associated with certain streptococcal diseases [63]. We therefore analyzed the virulence in a mouse model of several SDSE strains bearing different emm-types, but we were unable to find a significant correlation between emm-type of SDSE and virulence. Further studies are needed to provide further insight into the linkage between emm type of SDSE and infectivity in humans.

Streptococcal phages are considered critical in horizontal gene transfer, especially in the transport of virulence factors [28,70], in Streptococci. Three prophage elements in GGS_124 were found to be homologous to GAS prophages in both nucleotide and amino acid sequences. The positions of prophage insertion were also conserved between GGS_124 and previously sequenced GAS prophages, suggesting that SDSE and GAS share the same phage species, and that horizontal gene transfer between SDSE and GAS has occurred. However, GGS_124 does not contain prophages that encode genes for superantigens, Sla, or MF. These phage encoded genes were also missing from all strains previously analyzed by a GAS microarray [31]. Sdn is an exception, since it was detected in 4 of these 58 SDSE strains [31]. These results showed that SDSE may have some resistance to infection by GAS phages carrying genes encoding virulence factors.

Prokaryotes possess the CRISPR/Cas system, which mediates resistance to infection by foreign DNA, such as viruses [26,27]. GGS_124 has a CRISPR/Cas system, designated CRISPR1/Cas, whereas the other SDSE isolates analyzed in this study had another CRISPR/Cas system, designated CRISPR2/Cas. We found that SDSE strains usually have a higher total number of spacers than GAS, suggesting that prophage infection of SDSE was restricted to some extent, resulting in a smaller number of virulence factors located in the prophage regions of SDSE. Similar restrictions were observed in SESZ when compared with SESE. For example, the SESE 4047 genome, which contains no CRISPR, contains genes encoding virulence factors in prophage regions. In contrast, SESZ MGCS10565 


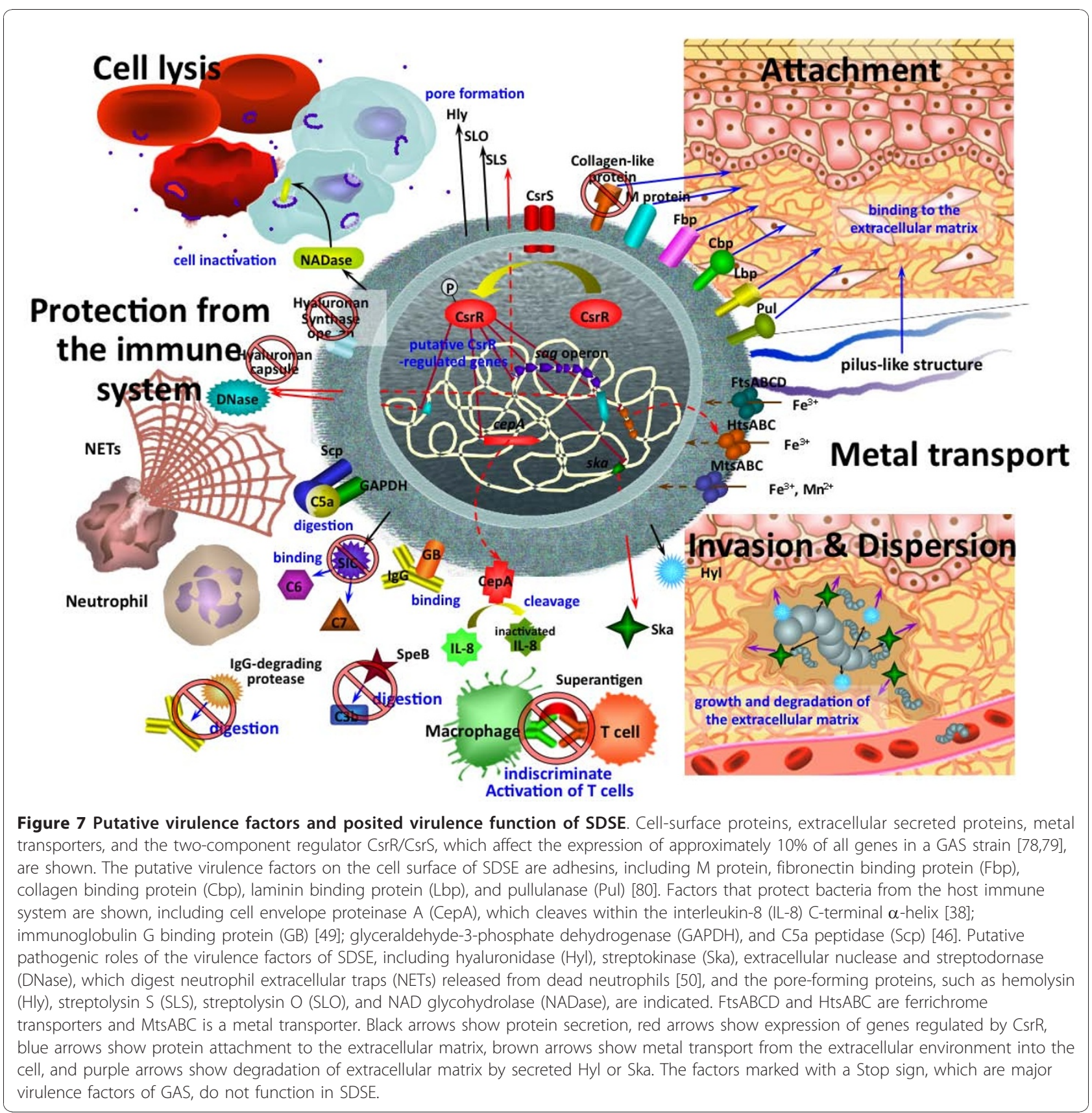

and H70, which contain 26 and 18 spacers, respectively, do not carry any prophages. Thus, the CRISPR system in streptococci sharing prophages may play a substantial role in the spread of virulence factors among species. Alternatively, these virulence factors may not benefit to SDSE during carriage or disease, such that the integration of these specific phages is not selected for.

\section{Conclusions}

We have shown here that SDSE likely acts as a pathogen, based on its genome sequence and close relationship with
GAS. As the frequency of isolation of SDSE from patients has increased, it should not be overlooked as a source of infection.

\section{Methods}

\section{Bacterial strains}

Three Streptococcus dysgalactiae subsp. equisimilis (SDSE) isolates, GGS_124, GGS_117, and GGS_118, were obtained from 3 patients with STSS, and 5 SDSE isolates were isolated from 5 patients with non-STSS (Table 1). All SDSE isolates were classified as Lancefield 
group G. Streptococcus pyogenes (GAS). NIH9 [71] was used as the SpeB-producing strain.

\section{emm typing}

The emm types were classified according to a protocol for emm typing of the Centers for Disease Control and Prevention (CDC) http://www.cdc.gov/ncidod/biotech/ strep/protocol_emm-type.htm.

\section{SDSE infection in mice}

All animal experiments were performed according to the guidelines of the Ethics Review Committees of Animal Experiments of Tokyo Women's Medical University and the National Center for Global Health and Medicine. Virulence in mice was determined as described [64]. Briefly, $\mathrm{LD}_{50}$ values were determined by intraperitoneal (i.p.) injection of each SDSE strain into 5 6-7 week old female ddY mice.

\section{Genome sequencing}

We obtained draft contig data of GGS_124 from a commercial service (454 Life Sciences, Branford, CT), and the gaps between the contigs were tiled by PCR after closure to validate assembly using specific primers or by primer walking and an ABI 3100 genetic analyzer (Applied Biosystems Inc., Foster City, CA). The percentage of QV40+ bases, an index of the quality of data from pyro-sequencing, was $99.87 \%$. The genome sequence of GGS_124 has been deposited in the DDBJ database (accession no. AP010935).

\section{Genome annotation and bioinformatics}

Transfer RNAs (tRNAs), transfer-messenger RNA (tmRNA), and rRNA sequences were predicted using ARAGORN [72]. Coding sequences (CDS) were predicted using in silico Molecular Cloning (In Silico Biology Inc., Yokohama City, Kanagawa, Japan) for selection of optimal start sites. Predicted genes and intergenic regions were compared using the NCBI sequence database http://blast.ncbi.nlm.nih.gov/Blast.cgi, and predicted CDS and start sites were adjusted accordingly. A genome-wide homology search was performed using the discontiguous megaBLAST algorithm http:// blast.ncbi.nlm.nih.gov/Blast.cgi with a word size of 11 and rewards and penalties $(2,-3)$ that optimize for alignments of about $85 \%$ identity. The phylogenetic tree of all sequenced Streptococcus species was constructed based on CVTree http://tlife.fudan.edu.cn/cvtree/[73]. Secretion signal peptides were predicted using SignalP http://www.cbs.dtu.dk/services/SignalP[74]. Sortases and cell wall sorting signals were predicted with available hidden Markov models using HMMER http://bamics3. cmbi.kun.nl/jos/sortase_substrates/help.html[75]. Clustered, regularly interspaced, short palindromic repeat
(CRISPR) spacers were detected using CRISPR Finder http://crispr.u-psud.fr/[76]. The phylogenetic tree of all sequenced Streptococcus was constructed based on the CVTree http://tlife.fudan.edu.cn/cvtree/[73]

\section{Detection and sequencing of CRISPRs and CRISPR-} associated protein (Cas) genes in the 8 SDSE strains CRISPRs and Cas genes in the SDSE strains were detected by conventional PCR using ExTaq (Takara Bio Inc., Otsu, Shiga, Japan) and the primers listed in Additional file 10. Template DNA was isolated as described [64]. The PCR cycling conditions were $94^{\circ} \mathrm{C}$ for $2 \mathrm{~min}$ followed by 30 cycles of $94^{\circ} \mathrm{C}$ for $30 \mathrm{~s}, 54^{\circ} \mathrm{C}$ for $30 \mathrm{~s}$, and $72^{\circ} \mathrm{C}$ for $4 \mathrm{~min}$, and a final extension at $72^{\circ} \mathrm{C}$ for $6 \mathrm{~min}$. The amplified CRISPR fragments were sequenced using an ABI 3100 genetic analyzer (Applied Biosystems Inc.). The CRISPR spacers were identified using CRISPR Finder http://crispr.u-psud.fr/[76]. The sequences of CRISPR and the spacers have been deposited in the DDBJ database (accession numbers are listed in Table 2).

\section{Determination of SpeB-like protease activity}

SpeB-like protease activity was assayed as described [77], with slight modifications. Briefly, DTT was added to bacterial culture supernatants to a final concentration of 10 $\mathrm{mM}$ and incubated at $37^{\circ} \mathrm{C}$ for $30 \mathrm{~min}$. An equal amount of $2 \mathrm{~g} / \mathrm{L}$ azocasein was added, and incubation was continued for an Additional $30 \mathrm{~min}$ at $37^{\circ} \mathrm{C}$. Trichloroacetic acid was added to a final concentration of $5 \%$, and incubation was continued for $15 \mathrm{~min}$ at $4{ }^{\circ} \mathrm{C}$. After centrifugation, an equal amount of $5 \mathrm{M} \mathrm{NaOH}$ was added to the supernatant, and its absorbance at $450 \mathrm{~nm}$ was measured.

\section{Distribution of putative virulence factors unique to GGS_124 among the other SDSE}

The distribution of putative virulence factors of GGS_124 among SDSE strains was analyzed by conventional PCR using ExTaq (Takara Bio Inc.) and the primers listed in Additional file 10. Template DNA extraction and PCR were performed as described [64].

\section{Additional material}

Additional file 1: Overview and comparison of the genome sequences of GGS_124 and genus Streptococcus available in databases as of January 2010.

Additional file 2: Unrooted phylogenetic tree of genus Streptococcus, including S. dysgalactiae subsp equisimilis GGS_124

The phylogenetic tree of all sequenced Streptococcus was constructed based on CVTree http://tlife.fudan.edu.cn/cvtree/[73], which constructs whole genome based phylogenetic trees without sequence alignment by using a Composition Vector (CV) approach. The genetic distances between the major nodes are shown.

Additional file 3: Genome rearrangement map of SDSE strain GGS_124 relative to GAS strains MGAS315 and strain SSI-1, and S. uberis $0140 \mathrm{~J}$. The genes were aligned from the predicted replication 
origin of each genome. The colored bars separating each genome represent similarity matches identified by in silico molecular cloning. BLASTP comparisons of CDS with GAS MGAS315 and SSI-1 and S. uberis 0140J are shown as amino acid identities of $\geq 90 \%$ (red), $89 \%-80 \%$ (orange), 79\%-70\% (yellow), 69\%-60\% (green), 59\%-50\% (light blue), and 49\%-40\% (dark blue). Prophages are highlighted as green boxes.

Additional file 4: GGS_124 genes showing higher similarity to genes from bacteria other than GAS, or no similarity to genes in the databases

Additional file 5: Features of CRISPR found in the GGS_124 genome and phages derived from GAS containing sequences homologous to GGS_124 spacers

Additional file 6: Putative virulence factors found in GGS_124 and their homologous genes in other streptococcal species

Additional file 7: Determination of SpeB-like protease activity in the SDSE isolates. SDSE (GGS 124 and GGS 118) and GAS (NIH9) were cultured in $\mathrm{BHI}$ in the presence or absence of $\mathrm{E}-64$, and the culture supernatants were analyzed for protease activity using azocasein as a substrate. The background activity of BHI is also shown.

Additional file 8: Distribution of the virulence factors found in SDSE among other streptococci

Additional file 9: Comparison of emm-type of GCS and GGS isolates from humans reported from 4 countries. Shown are emm-specific differences of SDSE in invasive and noninvasive infections from 1998 to 2004 in Portugal [65], the emm types of 128 strains of SDSE collected from 11 medical institutions in Japan from September 2003 to October 2005 [7], the emm types of 64 GCS and GGS isolates associated with noninvasive disease in western Norway from February 2005 to March 2006 [66], and the emm types of 212 invasive SDSE isolates collected in Atlanta, Georgia, from July 2002 to June 2004 and in the San Francisco Bay Area of California from January 2003 to December 2004 in the USA [3]. Each stack was ordered from higher (top) to lower isolation frequency (bottom).

Additional file 10: List of oligonucleotide primers used in this study.

\section{Acknowledgements}

The authors thank Mr. Hanasaki and Mr. Shimada for assisting in gap filling of the GGS_124 genome and animal experiments. This work was partly supported by a grant for Research on Emerging and Reemerging Infectious Diseases (H19 Shinkouh-02). T. M. A was supported by International Cooperation Research Grant (21A129) from the Ministry of Health, Labor, and Welfare of Japan.

\section{Author details}

'Department of Infectious Diseases, National Center for Global Health and Medicine, 1-21-1, Toyama, Shinjuku-ku, Tokyo 162-8655, Japan. ${ }^{2}$ Graduate School of Infection Control Science, Kitasato University, 5-9-1, Shirokane, Minato-ku, Tokyo 108-8641, Japan. ${ }^{3}$ Department of Microbiology and Immunology, Tokyo Women's Medical University, 8-1 Kawada-cho, Shinjukuku, Tokyo 162-8666, Japan. ${ }^{4}$ Department of Animal and Food Hygiene, Obihiro University of Agriculture and Veterinary Medicine, 2-11 Inada-cho, Obihiro, Hokkaido 080-8555, Japan.

\section{Authors' contributions}

YS and TMA performed the molecular genetic studies, participated in sequence alignment and drafted the manuscript. KO performed the molecular genetic studies and participated in sequence alignment. SYM and KU analyzed the genome sequences. JY, YS and TMA performed animal experiments. TK drafted the manuscript. UK, JY and TK conceived of the study, participated in its design and coordination, and helped to draft the manuscript. All authors read and approved the final manuscript.

Received: 7 June 2010 Accepted: 11 January 2011

Published: 11 January 2011

\section{References}

1. Lindbaek M, Hoiby EA, Lermark G, Steinsholt IM, Hjortdahl P: Clinical symptoms and signs in sore throat patients with large colony variant beta-haemolytic streptococci groups $\mathrm{C}$ or $\mathrm{G}$ versus group $\mathrm{A}$. $\mathrm{Br} J \mathrm{Gen}$ Pract 2005, 55:615-619.

2. Bramhachari PV, Kaul SY, McMillan DJ, Shaila MS, Karmarkar MG, Sriprakash KS: Disease burden due to Streptococcus dysgalactiae subsp. equisimilis (group $\mathrm{G}$ and $\mathrm{C}$ streptococcus) is higher than that due to Streptococcus pyogenes among Mumbai school children. J Med Microbiol 2010, 59:220-223.

3. Broyles LN, Van Beneden C, Beall B, Facklam R, Shewmaker PL, Malpiedi P, Daily P, Reingold A, Farley MM: Population-based study of invasive disease due to beta-hemolytic streptococci of groups other than $A$ and B. Clin Infect Dis 2009, 48:706-712.

4. Ekelund K, Skinhoj P, Madsen J, Konradsen HB: Invasive group A, B, C and G streptococcal infections in Denmark 1999-2002: epidemiological and clinical aspects. Clin Microbiol Infect 2005, 11:569-576.

5. Lopardo HA, Vidal $P$, Sparo $M$, Jeric $P$, Centron $D$, Facklam RR, Paganini $H$, Pagniez NG, Lovgren M, Beall B: Six-month multicenter study on invasive infections due to Streptococcus pyogenes and Streptococcus dysgalactiae subsp. equisimilis in Argentina. J Clin Microbiol 2005, 43:802-807.

6. Sunaoshi K, Murayama SY, Adachi K, Yagoshi M, Okuzumi K, Chiba N, Morozumi M, Ubukata K: Molecular emm genotyping and antibiotic susceptibility of Streptococcus dysgalactiae subsp. equisimilis isolated from invasive and non-invasive infections. J Med Microbiol 2010, 59:82-88.

7. Sunaoshi KS, Aburahashi H, Kobayashi R, Yamamoto Y, Okuzumi K, Yoshida A, Misawa Y, Adachi K, Ubukata K: Emm typing by genetic identification of Streptococcus dysgalactiae subsp. equisimilis and susceptibility to oral antibiotics. Kansenshogaku Zasshi 2006, 80:488-495.

8. Takahashi T, Ubukata K, Watanabe H: Invasive infection caused by Streptococcus dysgalactiae subsp. equisimilis: characteristics of strains and clinical features. J Infect Chemother 2010.

9. Reissmann S, Friedrichs C, Rajkumari R, Itzek A, Fulde M, Rodloff AC, Brahmadathan KN, Chhatwal GS, Nitsche-Schmitz DP: Contribution of Streptococcus anginosus to infections caused by groups $C$ and $G$ streptococci, southern India. Emerg Infect Dis 2010, 16:656-663.

10. Dawson ED, Taylor AW, Smagala JA, Rowlen KL: Molecular detection of Streptococcus pyogenes and Streptococcus dysgalactiae subsp. equisimilis. Mol Biotechnol 2009, 42:117-127.

11. Hilmarsdottir I, Valsdottir F: Molecular typing of Beta-hemolytic streptococci from two patients with lower-limb cellulitis: identica isolates from toe web and blood specimens. J Clin Microbiol 2007, 45:3131-3132.

12. Horii T, Izumida S, Takeuchi K, Tada T, Ishikawa J, Tsuboi K: Acute peritonitis and salpingitis associated with streptococcal toxic shock syndrome caused by Lancefield group $\mathrm{G}$ alpha-haemolytic Streptococcus dysgalactiae subsp. equisimilis. J Med Microbiol 2006, 55:953-956.

13. Kumar A, Sandoe J, Kumar N: Three cases of vertebral osteomyelitis caused by Streptococcus dysgalactiae subsp. equisimilis. J Med Microbiol 2005, 54:1103-1105.

14. Misawa Y, Okugawa S, Ubukata K, Okuzumi K, Okada M, Moriya K, Koike K: A case of severe necrotizing cellulitis caused by group G Streptococcus dysgalactiae subsp. equisimilis. Kansenshogaku Zasshi 2006, 80:436-439.

15. Moser C, Andresen K, Kjerulf A, Salamon S, Kemp M, Christensen JJ: Infective Arthritis: Bacterial 235 rRNA Gene Sequencing as a Supplementary Diagnostic Method. Open Microbiol J 2008, 2:85-88.

16. Savini V, Catavitello C, Talia M, Manna A, Pompetti F, Di Bonaventura G, Di Giuseppe N, Febbo F, Balbinot A, Di Zacomo S, Esattore F, D'Antonio D: Beta-lactam failure in treatment of two group $\mathrm{G}$ Streptococcus dysgalactiae subsp. equisimilis Pharyngitis patients. J Clin Microbiol 2008, 46:814-816.

17. Mott ML, Berger JM: DNA replication initiation: mechanisms and regulation in bacteria. Nat Rev Microbiol 2007, 5:343-354.

18. Nakagawa I, Kurokawa K, Yamashita A, Nakata M, Tomiyasu Y, Okahashi N, Kawabata S, Yamazaki K, Shiba T, Yasunaga T, Hayashi H, Hattori M, Hamada S: Genome sequence of an M3 strain of Streptococcus pyogenes reveals a large-scale genomic rearrangement in invasive 
strains and new insights into phage evolution. Genome Res 2003, 13:1042-1055.

19. Holden MT, Scott A, Cherevach I, Chillingworth T, Churcher C, Cronin A, Dowd L, Feltwell T, Hamlin N, Holroyd S, Jagels K, Moule S, Mungall K, Quail MA, Price C, Rabbinowitsch E, Sharp S, Skelton J, Whitehead S, Barrell BG, Kehoe M, Parkhill J: Complete genome of acute rheumatic fever-associated serotype M5 Streptococcus pyogenes strain manfredo. J Bacteriol 2007, 189:1473-1477.

20. McShan WM, Ferretti JJ, Karasawa T, Suvorov AN, Lin S, Qin B, Jia H, Kenton S, Najar F, Wu H, Scott J, Roe BA, Savic DJ: Genome sequence of a nephritogenic and highly transformable M49 strain of Streptococcus pyogenes. J Bacteriol 2008, 190:7773-7785

21. Banks DJ, Porcella SF, Barbian KD, Beres SB, Philips LE, Voyich JM, DeLeo FR, Martin JM, Somerville GA, Musser JM: Progress toward characterization of thegroup A Streptococcus metagenome: complete genome sequence of a macrolide-resistant serotype M6 strain. J Infect Dis 2004, 190:727-738.

22. Beres SB, Sesso R, Pinto SW, Hoe NP, Porcella SF, Deleo FR, Musser JM: Genome sequence of a Lancefield group C Streptococcus zooepidemicus strain causing epidemic nephritis: new information about an old disease. PLoS One 2008, 3:e3026.

23. Sumby P, Porcella SF, Madrigal AG, Barbian KD, Virtaneva K, Ricklefs SM, Sturdevant DE, Graham MR, Vuopio-Varkila J, Hoe NP, Musser JM: Evolutionary origin and emergence of a highly successful clone of serotype M1 group a Streptococcus involved multiple horizontal gene transfer events. J Infect Dis 2005, 192:771-782.

24. Green NM, Zhang S, Porcella SF, Nagiec MJ, Barbian KD, Beres SB, LeFebvre RB, Musser JM: Genome sequence of a serotype M28 strain of group a streptococcus: potential new insights into puerperal sepsis and bacterial disease specificity. J Infect Dis 2005, 192:760-770.

25. Smoot JC, Barbian KD, Van Gompel JJ, Smoot LM, Chaussee MS, Sylva GL, Sturdevant DE, Ricklefs SM, Porcella SF, Parkins LD, Beres SB, Campbell DS, Smith TM, Zhang Q, Kapur V, Daly JA, Veasy LG, Musser JM: Genome sequence and comparative microarray analysis of serotype M18 group A Streptococcus strains associated with acute rheumatic fever outbreaks. Proc Natl Acad Sci USA 2002, 99:4668-4673.

26. Brouns SJ, Jore MM, Lundgren M, Westra ER, Slijkhuis RJ, Snijders AP, Dickman MJ, Makarova KS, Koonin EV, van der Oost J: Small CRISPR RNAs guide antiviral defense in prokaryotes. Science 2008, 321:960-964.

27. Marraffini LA, Sontheimer EJ: CRISPR interference limits horizontal gene transfer in staphylococci by targeting DNA. Science 2008, 322:1843-1845.

28. Holden MT, Heather Z, Paillot R, Steward KF, Webb K, Ainslie F, Jourdan T, Bason NC, Holroyd NE, Mungall K, Quail MA, Sanders M, Simmonds M, Willey D, Brooks K, Aanensen DM, Spratt BG, Jolley KA, Maiden MC, Kehoe M, Chanter N, Bentley SD, Robinson C, Maskell DJ, Parkhill J, Waller AS: Genomic evidence for the evolution of Streptococcus equi: host restriction, increased virulence, and genetic exchange with human pathogens. PLoS Pathog 2009, 5:e1000346.

29. van der Ploeg JR: Analysis of CRISPR in Streptococcus mutans suggests frequent occurrence of acquired immunity against infection by M102like bacteriophages. Microbiology 2009, 155:1966-1976.

30. Horvath P, Barrangou R: CRISPR/Cas, the immune system of bacteria and archaea. Science 2010, 327:167-170.

31. Davies MR, McMillan DJ, Beiko RG, Barroso V, Geffers R, Sriprakash KS, Chhatwal GS: Virulence profiling of Streptococcus dysgalactiae subspecies equisimilis isolated from infected humans reveals 2 distinct genetic lineages that do not segregate with their phenotypes or propensity to cause diseases. Clin Infect Dis 2007, 44:1442-1454.

32. McMillan DJ, Vu T, Bramhachari PV, Kaul SY, Bouvet A, Shaila MS, Karmarkar MG, Sriprakash KS: Molecular markers for discriminating Streptococcus pyogenes and $\mathrm{S}$. dysgalactiae subspecies equisimilis. Eur $\mathrm{J}$ Clin Microbiol Infect Dis 2010, 29:585-589.

33. Betschel SD, Borgia SM, Barg NL, Low DE, De Azavedo JC: Reduced virulence of group A streptococcal Tn916 mutants that do not produce streptolysin S. Infect Immun 1998, 66:1671-1679.

34. Flanagan J, Collin N, Timoney J, Mitchell T, Mumford JA, Chanter N: Characterization of the haemolytic activity of Streptococcus equi. Microb Pathog 1998, 24:211-221.

35. Nakagawa I, Amano A, Mizushima N, Yamamoto A, Yamaguchi H, Kamimoto T, Nara A, Funao J, Nakata M, Tsuda K, Hamada S, Yoshimori T: Autophagy defends cells against invading group A Streptococcus. Science 2004, 306:1037-1040.
36. Zhao J, Hayashi T, Saarinen S, Papageorgiou AC, Kato H, Imanishi K, Kirikae T, Abe R, Uchiyama T, Miyoshi-Akiyama T: Cloning, expression, and characterization of the superantigen streptococcal pyrogenic exotoxin G from Streptococcus dysgalactiae. Infect Immun 2007, 75:1721-1729.

37. Kamezawa Y, Nakahara T, Nakano S, Abe Y, Nozaki-Renard J, Isono T: Streptococcal mitogenic exotoxin $Z$, a novel acidic superantigenic toxin produced by a T1 strain of Streptococcus pyogenes. Infect Immun 1997, 65:3828-3833.

38. Edwards RJ, Taylor GW, Ferguson M, Murray S, Rendell N, Wrigley A, Bai Z, Boyle J, Finney SJ, Jones A, Russell HH, Turner C, Cohen J, Faulkner L, Sriskandan S: Specific C-terminal cleavage and inactivation of interleukin8 by invasive disease isolates of Streptococcus pyogenes. J Infect Dis 2005, 192:783-790

39. Nishifuji K, Sugai M, Amagai M: Staphylococcal exfoliative toxins: "molecular scissors" of bacteria that attack the cutaneous defense barrier in mammals. J Dermatol Sci 2008, 49:21-31.

40. Lahteenmaki K, Kuusela P, Korhonen TK: Bacterial plasminogen activators and receptors. FEMS Microbiol Rev 2001, 25:531-552.

41. Chaussee MS, Gerlach D, Yu CE, Ferretti JJ: Inactivation of the streptococcal erythrogenic toxin B gene (speB) in Streptococcus pyogenes. Infect Immun 1993, 61:3719-3723.

42. Falugi F, Zingaretti C, Pinto V, Mariani M, Amodeo L, Manetti AG, Capo S, Musser JM, Orefici G, Margarit I, Telford JL, Grandi G, Mora M: Sequence variation in group A Streptococcus pili and association of pilus backbone types with lancefield T serotypes. J Infect Dis 2008, 198:1834-1841

43. Mora M, Bensi G, Capo S, Falugi F, Zingaretti C, Manetti AG, Maggi T, Taddei AR, Grandi G, Telford JL: Group A Streptococcus produce pilus-like structures containing protective antigens and Lancefield T antigens. Proc Natl Acad Sci USA 2005, 102:15641-15646.

44. Lauer P, Rinaudo CD, Soriani M, Margarit I, Maione D, Rosini R, Taddei AR, Mora M, Rappuoli R, Grandi G, Telford JL: Genome analysis reveals pili in Group B Streptococcus. Science 2005, 309:105.

45. Bjorck $L$, Kronvall G: Purification and some properties of streptococcal protein G, a novel lgG-binding reagent. J Immunol 1984, 133:969-974.

46. Terao Y, Yamaguchi M, Hamada S, Kawabata S: Multifunctional glyceraldehyde-3-phosphate dehydrogenase of Streptococcus pyogenes is essential for evasion from neutrophils. J Biol Chem 2006, 281:14215-14223.

47. Stollerman GH, Dale JB: The importance of the group a streptococcus capsule in the pathogenesis of human infections: a historical perspective. Clin Infect Dis 2008, 46:1038-1045.

48. Kumari K, Weigel PH: Molecular cloning, expression, and characterization of the authentic hyaluronan synthase from group C Streptococcus equisimilis. J Biol Chem 1997, 272:32539-32546.

49. Starr CR, Engleberg NC: Role of hyaluronidase in subcutaneous spread and growth of group A streptococcus. Infect Immun 2006, 74:40-48.

50. Buchanan JT, Simpson AJ, Aziz RK, Liu GY, Kristian SA, Kotb M, Feramisco J, Nizet V: DNase expression allows the pathogen group A Streptococcus to escape killing in neutrophil extracellular traps. Curr Biol 2006, 16:396-400.

51. Beiter K, Wartha F, Albiger B, Normark S, Zychlinsky A, Henriques-Normark B An endonuclease allows Streptococcus pneumoniae to escape from neutrophil extracellular traps. Curr Biol 2006, 16:401-407.

52. Brinkmann V, Reichard U, Goosmann C, Fauler B, Uhlemann Y, Weiss DS, Weinrauch Y, Zychlinsky A: Neutrophil extracellular traps kill bacteria. Science 2004, 303:1532-1535.

53. Hasegawa T, Minami M, Okamoto A, Tatsuno I, Isaka M, Ohta M: Characterization of a virulence-associated and cell-wall-located DNase of Streptococcus pyogenes. Microbiology 2010, 156:184-190.

54. Nitsche DP, Johansson HM, Frick IM, Morgelin M: Streptococcal protein FOG, a novel matrix adhesin interacting with collagen I in vivo. I Biol Chem 2006, 281:1670-1679.

55. Barroso V, Rohde M, Davies MR, Gillen CM, Nitsche-Schmitz DP, Dinkla K Chhatwal GS: Identification of active variants of PARF in human pathogenic group $C$ and group $\mathrm{G}$ streptococci leads to an amended description of its consensus motif. Int I Med Microbiol 2009, 299:547-553.

56. Binks M, Sriprakash KS: Characterization of a complement-binding protein DRS, from strains of Streptococcus pyogenes containing the emm 12 and emm55 genes. Infect Immun 2004, 72:3981-3986. 
57. Sagar V, Kumar R, Ganguly NK, Menon T, Chakraborti A: DRS is far less divergent than streptococcal inhibitor of complement of group $\mathrm{A}$ streptococcus. J Bacteriol 2007, 189:2933-2935.

58. Fernie-King BA, Seilly DJ, Davies A, Lachmann PJ: Streptococcal inhibitor of complement inhibits two Additional components of the mucosal innate immune system: secretory leukocyte proteinase inhibitor and lysozyme. Infect Immun 2002, 70:4908-4916.

59. Hartas J, Sriprakash KS: Streptococcus pyogenes strains containing emm12 and emm55 possess a novel gene coding for distantly related SIC protein. Microb Pathog 1999, 26:25-33.

60. Caswell CC, Barczyk M, Keene DR, Lukomska E, Gullberg DE, Lukomski S: Identification of the first prokaryotic collagen sequence motif that mediates binding to human collagen receptors, integrins alpha2beta1 and alpha11beta1. J Biol Chem 2008, 283:36168-36175.

61. Kimoto H, Fujii Y, Yokota Y, Taketo A: Molecular characterization of NADase-streptolysin O operon of hemolytic streptococci. Biochim Biophys Acta 2005, 1681:134-149.

62. Madden JC, Ruiz N, Caparon M: Cytolysin-mediated translocation (CMT): a functional equivalent of type III secretion in gram-positive bacteria. Cell 2001, 104:143-152.

63. Cunningham MW: Pathogenesis of group A streptococcal infections. Clin Microbiol Rev 2000, 13:470-511.

64. Miyoshi-Akiyama T, Zhao J, Kikuchi K, Kato H, Suzuki R, Endoh M, Uchiyama T: Quantitative and qualitative comparison of virulence traits, including murine lethality, among different $M$ types of group $A$ streptococci. J Infect Dis 2003, 187:1876-1887.

65. Pinho MD, Melo-Cristino J, Ramirez M: Clonal relationships between invasive and noninvasive Lancefield group $C$ and $\mathrm{G}$ streptococci and emm-specific differences in invasiveness. J Clin Microbiol 2006, 44:841-846.

66. Kittang BR, Langeland N, Mylvaganam H: Distribution of emm types and subtypes among noninvasive group A, C and $G$ streptococcal isolates in western Norway. APMIS 2008, 116:457-464.

67. Bentley RW, Leigh JA, Collins MD: Intrageneric structure of Streptococcus based on comparative analysis of small-subunit rRNA sequences. Int J Syst Bacteriol 1991, 41:487-494.

68. Chatellier S, Harel J, Zhang Y, Gottschalk M, Higgins R, Devriese LA, Brousseau R: Phylogenetic diversity of Streptococcus suis strains of various serotypes as revealed by $16 \mathrm{~S}$ rRNA gene sequence comparison. Int J Syst Bacteriol 1998, 48 Pt 2: 581-589.

69. Sachse S, Seidel P, Gerlach D, Gunther E, Rodel J, Straube E, Schmidt KH: Superantigen-like gene(s) in human pathogenic Streptococcus dysgalactiae, subsp equisimilis: genomic localisation of the gene encoding streptococcal pyrogenic exotoxin G (speG(dys)). FEMS Immunol Med Microbiol 2002, 34:159-167.

70. Ikebe T, Wada A, Inagaki Y, Sugama K, Suzuki R, Tanaka D, Tamaru A, Fujinaga $Y$, Abe $Y$, Shimizu Y, Watanabe H: Dissemination of the phageassociated novel superantigen gene speL in recent invasive and noninvasive Streptococcus pyogenes M3/T3 isolates in Japan. Infect Immun 2002, 70:3227-3233.

71. Miyoshi-Akiyama T, Ikebe T, Watanabe H, Uchiyama T, Kirikae T, Kawamura $Y$ : Use of DNA arrays to identify a mutation in the negative regulator, csrR, responsible for the high virulence of a naturally occurring type M3 group A streptococcus clinical isolate. J Infect Dis 2006, 193:1677-1684.

72. Laslett D, Canback B: ARAGORN, a program to detect tRNA genes and tmRNA genes in nucleotide sequences. Nucleic Acids Res 2004, 32:11-16.

73. Xu Z, Hao B: CVTree update: a newly designed phylogenetic study platform using composition vectors and whole genomes. Nucleic Acids Res 2009, 37:W174-8.

74. Bendtsen JD, Nielsen H, von Heijne G, Brunak S: Improved prediction of signal peptides: SignalP 3.0. J Mol Biol 2004, 340:783-795.

75. Boekhorst J, de Been MW, Kleerebezem M, Siezen RJ: Genome-wide detection and analysis of cell wall-bound proteins with LPxTG-like sorting motifs. J Bacteriol 2005, 187:4928-4934.

76. Grissa I, Vergnaud G, Pourcel C: CRISPRFinder: a web tool to identify clustered regularly interspaced short palindromic repeats. Nucleic Acids Res 2007, 35:W52-7.

77. Kuo CF, Wu JJ, Lin KY, Tsai PJ, Lee SC, Jin YT, Lei HY, Lin YS: Role of streptococcal pyrogenic exotoxin $B$ in the mouse model of group $A$ streptococcal infection. Infect Immun 1998, 66:3931-3935.
78. Gryllos I, Grifantini R, Colaprico A, Jiang S, Deforce E, Hakansson A, Telford JL, Grandi G, Wessels MR: Mg(2+) signalling defines the group A streptococcal CsrRS (CovRS) regulon. Mol Microbiol 2007, 65:671-683.

79. Graham MR, Virtaneva K, Porcella SF, Gardner DJ, Long RD, Welty DM, Barry WT, Johnson CA, Parkins LD, Wright FA, Musser JM: Analysis of the transcriptome ofgroup A Streptococcus in mouse soft tissue infection. Am J Pathol 2006, 169:927-942.

80. Hytonen J, Haataja S, Finne J: Streptococcus pyogenes glycoproteinbinding strepadhesin activity is mediated by a surface-associated carbohydrate-degrading enzyme, pullulanase. Infect Immun 2003, 71:784-793.

doi:10.1186/1471-2164-12-17

Cite this article as: Shimomura et al:: Complete genome sequencing and analysis of a Lancefield group G Streptococcus dysgalactiae subsp. equisimilis strain causing streptococcal toxic shock syndrome (STSS). BMC Genomics 2011 12:17.

\section{Submit your next manuscript to BioMed Central and take full advantage of:}

- Convenient online submission

- Thorough peer review

- No space constraints or color figure charges

- Immediate publication on acceptance

- Inclusion in PubMed, CAS, Scopus and Google Scholar

- Research which is freely available for redistribution

Submit your manuscript at www.biomedcentral.com/submit
Biomed Central 